\title{
Spectroscopic Analysis of Selected Priority Trace Metals in the Extant East African Gilled Lungfish (Protopterus amphibius) in Lira Municipal Lagoon and Its Edibility Health Risk
}

\author{
Timothy Omara ${ }^{1,2,3,4,}$, , Remish Ogwang ${ }^{3}$, Sarah Ndyamuhaki ${ }^{2}$, Sarah Kagoya ${ }^{3}$, Erisa Kigenyi ${ }^{3,4}$, \\ Bashir Musau $^{3,4}$, Eddie Adupa ${ }^{3,5}$ \\ ${ }^{1}$ Department of Health Sciences, Unicaf University, Lusaka, Zambia \\ ${ }^{2}$ Department of Quality Control, Quality Assurance and Product Development, Agro Ways Uganda Limited, Jinja, Uganda \\ ${ }^{3}$ Department of Chemistry, Faculty of Science, Kyambogo University, Kampala, Uganda \\ ${ }^{4}$ Department of Quality Control and Quality Assurance, Leading Distillers Uganda Limited, Kampala, Uganda \\ ${ }^{5}$ Department of Quality Control and Quality Assurance, Abacus Parenteral Drugs Limited, Mukono, Uganda
}

Email address:

prof.timo2018@gmail.com (T. Omara),ogwangremish@gmail.com (R. Ogwang), sarah.ndyamuhaki@agroways.ug (S. Ndyamuhaki), kagoyasarah5@gmail.com (S. Kagoya),erisakp@gmail.com (E. Kigenyi),musaubashirr22@gmail.com (B. Musau), adupaeddie39@gmail.com (E. Adupa)

*Corresponding author

\section{To cite this article:}

Timothy Omara, Remish Ogwang, Sarah Ndyamuhaki, Sarah Kagoya, Erisa Kigenyi, Bashir Musau, Eddie Adupa. Spectroscopic Analysis of Selected Priority Trace Metals in the Extant East African Gilled Lungfish (Protopterus amphibius) in Lira Municipal Lagoon and Its Edibility Health Risk. Science Journal of Analytical Chemistry. Vol. 6, No. 5, 2018, pp. 38-45. doi: 10.11648/j.sjac.20180605.11

Received: November 7, 2018; Accepted: November 21, 2018; Published: December 24, 2018

\begin{abstract}
This investigation analyzed the concentrations of three trace metals in gilled lungfish of Lira Municipal lagoon of Lira District and estimated the health risk associated with its consumption. Three fresh lungfish samples from the down, middle and up sluices of the lagoon were caught, eviscerated, washed and sundried. Edible muscles of the samples were oven dried at $105^{\circ} \mathrm{C}$, desiccated and pulverized. $2.0 \pm 0.1 \mathrm{~g}$ of the fine fish powders were ashed at $550^{\circ} \mathrm{C}$, acid digested, and the filtrates used to prepare 1 litre sample solutions. The sample solutions were analyzed for Lead, Zinc and Cadmium by Atomic absorption spectrometry. Spectroscopic results showed that no Cadmium was detected while the statistical mean concentrations of Zinc and Lead in the fishes from down, middle and up streams in $\mathrm{mg} / \mathrm{kg}$ were $157.8 \pm 0.01,160.2 \pm 0.02,158.2 \pm 0.01$ and $6.84 \pm 0.01$, $1.69 \pm 0.03,5.12 \pm 0.01$ respectively. The above results showed that the trace metals in the investigated fish samples are deleteriously above the maximum permissible Zinc $(0.7 \mathrm{mg} / \mathrm{kg})$ and Lead $(0.3 \mathrm{mg} / \mathrm{kg})$ levels in fish indicated by CODEX STAN 193-1995. The statistical Estimated Daily Intakes were from 26.27 to $26.66 \mathrm{mg} / \mathrm{kg} /$ day for Zinc and 0.28 to $1.48 \mathrm{mg} / \mathrm{kg} / \mathrm{day}$ for Lead. A heightened Health Risk Index value of 88.67 for Zinc was observed in the middle stream lungfish samples while Lead had the lowest Health Risk Index value of 2.00 in the middle stream fish from the lagoon. All the Health Risk Index values were greater than unity except for Chromium that was undetected in the fish muscles thus the lungfish of the lagoon is unsafe for human consumption and continuous consumption will impact human health. The immediate strategy lies in fencing the lagoon area and putting a stringent restriction against fishing from the lagoon.
\end{abstract}

Keywords: Cadmium, Estimated Daily Intake, Lead, Health Risk Index, Target Hazard Quotient, Zinc

\section{Introduction}

Lira is one of the heavily industrialized nascent cities in
Northern Uganda characterized by multifold anthropogenic activities due to its voluminous production of sunflower (Helianthus annus), maize (Zea mays L.), simsim (Sesamum indicum), cassava (Manihot esculenta), sand and clay mining, 
crude waragi making and natural endowment with Shea butter (Vitellaria nilotica). These accentuated a swift population increase following the two-decade rebel and heterodox Christian insurgency of the Lord's Resistance Army and Karimojong incursions that culminated in an increased volume of approximated 110 tons per day of wastes generated [1]. Lira Municipal lagoon (LML) is a collection point for at least $30 \%$ of the accessible generated wastes $[1,2]$. The lagoon in which the wastes are deposited is a demonstrated breeding-ground for a school of the extant East African gilled lungfish, Protopterus amphibius. On account of its high innate proteinaceous composition, the demand for esculent fish is a hot cake city over. Nutritionwise, the additional relevance of fish is rooted in its ethnomedical inherent vitamins and omega-3 polyunsaturated docosahexaenoic and eicosapentenoic fatty acids popularized as essential for regulation of body cholesterol levels and minimization of psychiatric, neurodegenerative and cardiac diseases as well as stroke and premature delivery. The wastes of LML is a potential source of heavy metals yet there is illegal fishing out of the lungfish by the local people for consumption and sale.

A heavy metal is chemically an element with a high molecular weight and high specific gravity (or equivalently high density, at least five times greater than that of water) which produces toxicity by complexation or ligand-formation with organic compounds and active sites of enzymes even at very meagre concentrations. Trace metals of exhibited essence in normal fish metabolism include Iron $(\mathrm{Fe})$, Copper $(\mathrm{Cu})$, Zinc (Zn) and Manganese (Mn) [3] while Aluminum (Al), Cobalt (Co), Tin (Sn), Vanadium (V), Nickel (Ni), Selenium (Se), Scandium (Sc), Molybdenum (Mo), Boron (B), Mercury (Hg), Cadmium (Cd), Arsenic (As), Chromium (Cr), Thallium $(\mathrm{Tl})$, Lead $(\mathrm{Pb})$, Silver $(\mathrm{Ag})$ and Antimony $(\mathrm{Sb})$ are non-essential and are usually accumulated in fish organs [4]. They cannot be degraded or metabolized cheaply and tend to bioconcentrate in living tissues. Unprecedented trace metal degradation of aquatic entities surpassing natural containable limits is among the austere and most sincere voices of current researchers [5], as these has vitiated fish quality with appreciable exposures at lethal and antagonistic concentrations posing human health threats $[3,6-8]$ in form of headache, human organ disorders $[9,10]$, pneumonia, diarrhea, elevated post-menopausal breast cancer chances [11], depression, hemoglobinuria and ultimately death. Thus, trace metals have received United States Environmental Protection Agency categorization [12] with clearly documented threshold limits for humans [13-15]. In fact, WHO and FAO voiced an alarm that the eight priority trace metals: Zinc, Lead, Cadmium, Mercury, Arsenic, Copper, Iron, Tin should closely and mandatorily be monitored in edible fish [10]. Fish ingest heavy metals via food and direct water uptake $[16,17]$ or epithelial ingestion of water that sluices through their gills, skin, oral cavity and digestive tract [18]. Upon absorption, heavy metals are ferried into the blood stream and other storage organs like bones, kidney and the liver for possible storage, detoxification and/or elimination. Chronic intake of heavy metals by fish rests entirely on the trace metal concentration, volume of the ingested food, the heavy metal uptake speed, exposure duration, uptake route, ecological conditions external to the fish (including availability of water, temperature, $\mathrm{pH}$ ) and innate factors notably fish age [19], fish nutritional habits as well as the dynamic processes involved in the trace metal metabolism [20-22]. According to Weber et al [23], aquatic organisms, including fish, exposed to copious levels of waterborne trace metals bioconcentrate the metals upon absorption, ultimately transferring them to humans as they are inevitable in human nutrition . Adhikari et al [24] found that comestible muscles of fish from Kolleru Lake, India housed the least content of trace metals among all the tissues investigated. They attributed this to the indirect connection between edible muscles as trace metals are usually solvated with water molecules. Concentrations of Cadmium, Nickel and Lead in selected tissues of 13 fish species from the lower reach of Kelantan River, Malaysia was assessed by Hashim et al [25]. In their results, the level of Cadmium in Barbonymus gonionatus and Tachysurus maculatus were exceptionally above acceptable limits whereas the other fish species had Cadmium almost surpassing the permissible limits. All the fish samples in their study had Nickel below the permissible limit though Osteochilus hasseltii and $T$. maculatus showed high Lead contents of $0.169 \mathrm{mg} / \mathrm{kg}$ and $0.156 \mathrm{mg} / \mathrm{kg}$ with the levels of the metals differing seasonally. Omnivorous species registered high Cadmium and Nickel levels while Lead was registered at heightened levels in carnivorous species [25]. Levels of Manganese, Iron, Copper, Zinc, Cadmium and Lead were evaluated in water and dorsal muscle of Nile tilapia (Oreochromis niloticus) from aquacultures watered with normal and sludge water at Al-Abbassa and Shader Azzam, Egypt by Mostafa et al [26]. They reported that Iron had the highest marked average content in the water of the dams while Cadmium had the lowest concentration. The mean metal concentrations in the fish tissues reported descended in the sequence Zinc $>$ Iron $>$ Copper $>$ Manganese $>$ Lead $>$ Cadmium. Mean concentrations of Copper, Cadmium and Lead in the edible muscles were greater in Shader Azzam fish farm. Investigations of Anand and Kumarasamy [27] unveiled the statistical concentrations of trace metals in some fish organs followed the descending pattern Copper $>$ Lead $>$ Cadmium $>$ Nickel $>$ Cobalt with Copper and Cobalt most and least prevalent respectively in the fishes on the East coastal region of Valinokkam, Ramanathapuram District, Tamilnadu. All the trace metals in the studied fishes were well below the maximum permissible limits. Darko et al [28] evaluated the trace metal toxicity risks connected with consumption of sewage fish polluted with heavy metals in some Ghanaian fish ponds. Their findings revealed that all the edible fish investigated housed trace metals; Lead, Cadmium, Copper, Chromium and Mercury in the water samples of concentrations $28.7,18.2,246.0,310.0$ and $150.0 \mu \mathrm{g} / \mathrm{kg}$ respectively. The maximum contents of Lead, Copper, Chromium and Mercury in the sediments recorded were 27.4, $323.0,240.0$ and $150.0 \mu \mathrm{g} / \mathrm{kg}$. The maximum concentrations of Lead, Copper, Cadmium, Chromium and Mercury in the fish samples were 48.6, 434.0, 18.9, 300.0 and $320 \mu \mathrm{g} / \mathrm{kg}$ 
respectively, which were well below the European Union permissible trace metal limits. The estimated daily intakes were from $1 \times 10^{-6}$ to $6 \times 10^{-5} \mathrm{mg} / \mathrm{kg} / \mathrm{day}$ while all the Health Risk Indices were less than 1.0 which implied no potential trace metal toxicity risk from feeding on the pond fish [28]. A spectroscopic investigation by Shovon, Majumdar and Rahman [29] evaluated the concentrations of Lead, Cadmium and Nickel in some selected organs of Labeo rohita, Gibelion catla and Pangasius hypophthalmus edible fishes from Kawran Bazar fish market, Bangladesh. Their findings revealed that the most prevalent non-essential trace metal was Lead of $48.33 \pm 2.52 \mathrm{mg} / \mathrm{L}$ in the gill of P. hypophthalmus and the lowest recorded Lead content of $23.33 \pm 2.52 \mathrm{mg} / \mathrm{L}$ was in $L$ rohita sex gland. Elevated Cadmium prevalence was noted at $0.96 \pm 0.08 \mathrm{mg} / \mathrm{L}$ in $L$. rohita gills and the lowest content of $0.02 \pm 0.01 \mathrm{mg} / \mathrm{L}$ was detected in P. hypophthalmus kidney. Nickel was at the highest concentration of $6.63 \pm 1.00 \mathrm{mg} / \mathrm{L}$ in L. rohita gill whereas the lowest concentration of $0.10 \pm$ $0.10 \mathrm{mg} / \mathrm{L}$ was reported in the liver of L. rohita. Only Lead surpassed the regulatory limits for trace metals in the fish species investigated [29]. There is finite available published data on heavy metal composition of sewages and fishes in Uganda. However, heavy metal and toxin poisoning of fish in some lakes including Lake Victoria and Lake Muburo have been investigated by some authors [12, 30-32]. Unfortunately, no published information is available on the heavy metal content of the edible muscles of the lungfish consumed by the population of Lira Municipal Lagoon. This investigation therefore analyzed three priority trace metals (Zinc, Lead and Cadmium) in Lungfish of Lira Municipal lagoon of Lira District and estimated the possible edibility health risk associated with its consumption.

\section{Materials and Methods}

\subsection{Site Description}

Lira municipal lagoon is situated in the heart of Lira municipality and harbors a relatively huge school of the extant East African gilled lungfish. The actual site is in Ojwina division, Bar-Ogole village near Cuk-Atat market, a slum area within the municipality. The lagoon waste stream is composed of solid and liquid wastes from domestic waste water sinks, street cleanings, leather, wastes from local people carrying out crude waragi distillation, textiles, grey water, medical wastes from hospital washrooms, washed away paints, preserved woods and wood shavings, rubber, glass, surface runoffs, industrial effluents, fossil wastes from automobile exhausts and service stations, milling activities near the sewage site, corrosions from drainage pipes, agricultural fertilizers and pesticides, wearing of machinery, dead lead accumulators and dust [2] which may reasonably contain heavy metals. Industries operating within the municipality along Station road in Lira Industrial area include Mount Meru millers, Guru-Nanak Oil Mills, A. K Fats and Oils), Tip Top bakeries, Beb wine industries and Nile Breweries Limited [2]. Waste management involves collection of accessible solid wastes in skips provided by municipal authorities which are loaded in trucks and transported to the dumping site in Aler $[1,2]$. Liquid wastes are drained from septic tanks to sewage site using plumbed drainage pipes constructed underground. There is a twin sewerage system which are; western sewerage (2.1 km long, $100 \mathrm{~m}$ radius and 31 hectares total area) and Eastern system $(7.5 \mathrm{~km}$ long, occupying 142 hectares, within a $100 \mathrm{~m}$ radius). The sewerage is thus overall $9.6 \mathrm{~km}$, covering 173 hectares of land [2].

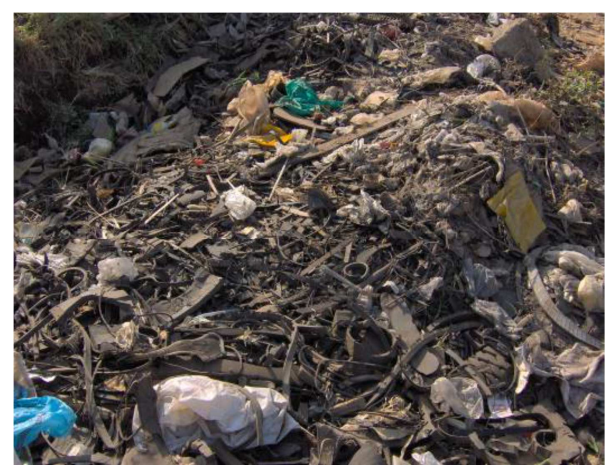

(a)

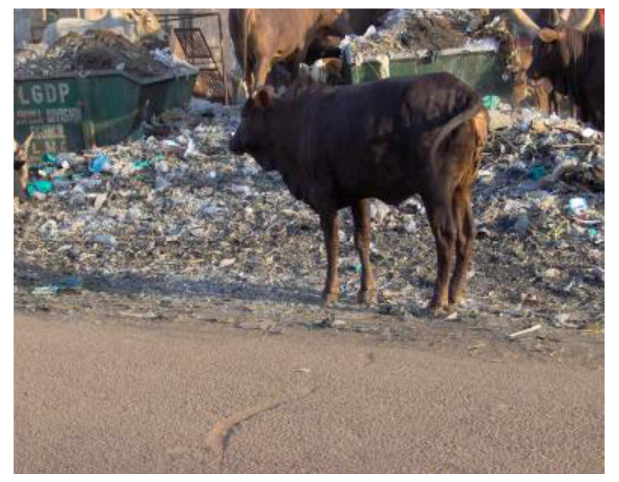

(b)

Figure 1. (a) Remains of old cut car tyres used for making of local footwear 'olal'. (b) A garbage skip at Lira Main Bus park, approximately $700 m$ away from the lagoon. Source:[2].

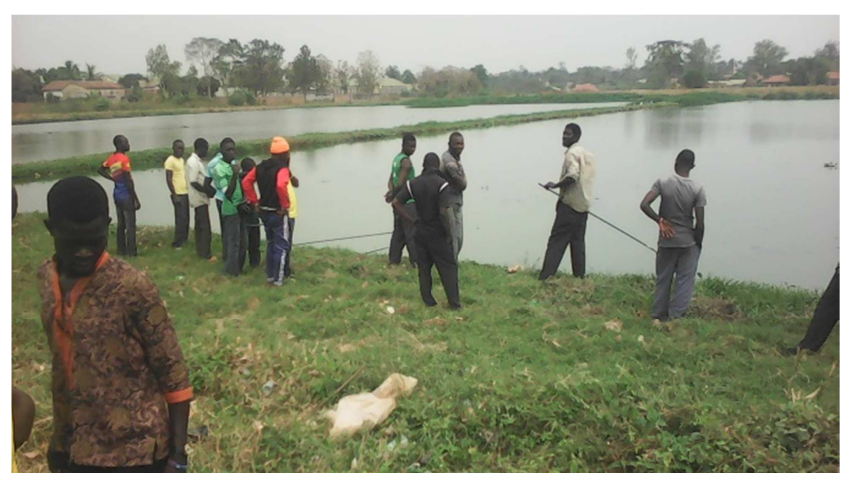

Figure 2. Lira Municipal Lagoon.

\subsection{Fish Sample Collection}

Three fresh lung fish samples were caught in series on $19^{\text {th }}$ January 2018 between 10:30-11:40 a.m (East African Standard Time) from the downstream, midstream and 
upstream of the lagoon using hooks fed with earthworms as baits. The nine (9) lung fish samples were taken offshores in a dish of water where they were eviscerated, washed and spread in the sun to dry for 2 hours.

\subsection{Fish Sample Preparation}

Secondary drying of whole edible parts of the fish samples were done in an electric oven at $105^{\circ} \mathrm{C}$ for 48 hours and put in the desiccator to attain room temperature. The muscles of the dried fish samples were then pulverized using a clean a porcelain mortar and pestle to obtain fine fish powders. $2.0099 \pm 0.01 \mathrm{~g}$ aliquots of the homogenized fish powders were ashed in a furnace at $550^{\circ} \mathrm{C}$ for 3 hours. The ashed samples were then transferred to $250 \mathrm{ml}$ volumetric flasks. Measured $15 \mathrm{ml}$ of $6 \mathrm{M}$ Nitric acid and $5 \mathrm{ml}$ of $5 \mathrm{M}$ concentrated Hydrochloric acid in the ratio of 3:1 were added to the flasks and the samples were digested for 15 minutes, filtered into $100 \mathrm{ml}$ standard volumetric flasks and made to the marks with sterile double distilled water.

\subsection{Spectroanalytical Procedure}

A $20 \%$ blank solution prepared using $15 \mathrm{ml}$ of $63 \%$ Nitric acid (Sigma-Aldrich) and $5 \mathrm{ml}$ of $98 \%$ Sulphuric acid was run first to remove any traces of background interferences that would otherwise cause inaccuracy of the spectroscopic results. Each digested sample of lungfish was analyzed for heavy metals: Lead, Zinc and Cadmium using AA 6300 Shimadzu Double beam Atomic Absorption Spectrophotometer (Shimadzu Corporation, Japan). Nitrate salts (analytical purity $>99.9 \%$ ) of Zinc, Cadmium and Lead were used to prepare $1000 \mathrm{mg} / \mathrm{L}$ standard stock solutions and serial dilutions (working solutions). The Atomic absorption spectrometer was switched on 2 hours prior to the analysis and the corresponding metal hollow cathode lamps and wavelengths fixed for each metal $(232.0 \mathrm{~nm}$ for Lead, $213.9 \mathrm{~nm}$ for Zinc and 228.8nm for Cadmium). Air-acetylene flame was used. Five different sets of standards for each metal were run in triplicates and then sprayed into flame as well as their respective samples and the corresponding absorbances were taken. Each sample was ran in triplicate and the absorbance results obtained were used to compute the concentrations of the metals from the standard curves. The results in $\mathrm{mg} / \mathrm{L}$ from the instrument were converted to the standard unit for solid foods $(\mathrm{mg} / \mathrm{Kg})$ for comparison with the set international critical limits using (1):

$$
\text { Concentration }=\frac{\text { Concentration in } \mathrm{ppm}}{\text { Weight of sample in } \mathrm{Kg}}
$$

\subsection{Target Hazard Quotient (THQ)}

Estimated Daily Intake (EDI) adopted from US-EPA Region III risk-based concentration table [33] and Wang et al [34] was computed using (2):

$$
E D I=\frac{E_{f} \times E_{d} \times F_{i r} \times C_{f} \times C_{h m}}{W_{a b} \times T_{a e t}}
$$

From which $E_{f}$, is the exposure frequency (365 days per year); $E_{\mathrm{d}}$ is, the exposure duration, equivalent to average lifetime (58.65 years for an adult Ugandan) [35]; $F_{\text {ir }}$ is the fresh food ingestion rate $(\mathrm{g} /$ person/day), equal to $48 \mathrm{~g} /$ person/day for fish [36]; $C_{\mathrm{f}}$ is the conversion factor $(0.208)$ for fresh weight $\left(F_{\mathrm{w}}\right)$ to dry weight $\left(D_{\mathrm{w}}\right), C_{\mathrm{hm}}$ is the heavy metal concentration in foodstuffs $\left(\mu \mathrm{g} / \mathrm{kg} F_{\mathrm{w}}\right) ; W_{a b}$ is the average body weight (average adult body weight was considered to be $60 \mathrm{~kg}$ [36]) and $T_{\text {aet }}$ is, the average exposure time for non-carcinogens (given by the product of $E_{\mathrm{d}}$ and $E_{\mathrm{f}}$ ) [37]. Health Risk Index (HRI) of trace metal polluted lungfish consumed by the local community was evaluated using THQ in accordance with US-EPA Region III risk-based concentration table [33] and Bortey-Sam et al [38]. According to the criterion, THQ (HRI) less than unity implies the exposure is very unlikely to have adverse effects whereas THQ greater than unity prognosticates a possibility of non-carcinogenic effects, with an increasing probability as the value increases [34]. The numerical Health Risk Index (HRI) values were obtained from computations using (3);

$$
\mathrm{THQ}=\frac{\mathrm{EDI}}{R O D}
$$

The Reference Oral Doses (ROD) in $\mathrm{mg} / \mathrm{kg} / \mathrm{day}$ for Zinc, Lead and Cadmium are respectively $3.0 \times 10^{-1}, 1.4 \times 10^{-1}$ and $1.0 \times 10^{-3}[33]$.

\section{Results and Statistical Analysis}

Descriptive characteristics that is; the Mean of the heavy metal concentrations of triplicate analyses, their Standard Deviations (S. D), Standard Error (S. E) and the statistically significant differences between the bioconcentration of the selected heavy metals in the lungfish samples from the different sluices of the lagoon were determined using Minitab statistical software (v18, Minitab Inc., USA). The corresponding EDI and THQ of the samples are given in Table 2.

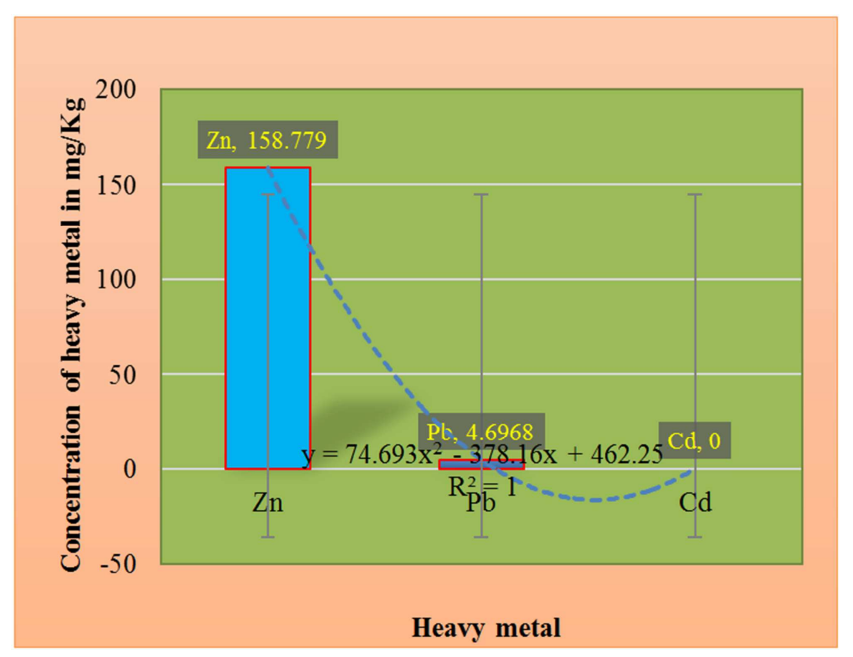

Figure 3. Mean concentrations of the selected priority trace metals in the lungfish samples. 
Table 1. Trace metal concentrations ( $\mathrm{mg} / \mathrm{kg}$ ) in the fish samples.

\begin{tabular}{llll}
\hline Sluice & Zinc & Lead & Cadmium \\
\hline Downstream & $157.0 \pm 0.01^{+}$ & $6.84 \pm 0.01^{+}$ & BDL \\
Middle stream & $160.0 \pm 0.02$ & $1.69 \pm 0.03$ & BDL \\
Upstream & $158.2 \pm 0.01$ & $5.12 \pm 0.01$ & BDL \\
FAO/WHO limit & 0.70 & 0.30 & 0.0003 \\
\hline
\end{tabular}

${ }^{+}$Means are presented as Mean \pm Standard Error, BDL-Below Detection Limit

Table 2. Estimated Daily Intake and the Target Hazard Quotient of the heavy metals in the fish samples.

\begin{tabular}{lllllll}
\hline \multirow{2}{*}{ Sluice } & \multicolumn{2}{l}{ EDI $(\mathbf{m g} / \mathbf{k g} / \mathbf{d a y})$} & \multicolumn{2}{l}{ THQ } & \\
\cline { 2 - 7 } & $\mathbf{Z n}$ & $\mathbf{P b}$ & $\mathbf{C d}$ & $\mathbf{Z n}$ & $\mathbf{P b}$ & $\mathbf{C d}$ \\
\hline Downstream & 26.27 & 1.14 & 0.00 & 87.57 & 8.14 & 0.00 \\
Middle stream & 26.66 & 0.28 & 0.00 & 88.67 & 2.00 & 0.00 \\
Upstream & 26.33 & 0.85 & 0.00 & 87.77 & 6.07 & 0.00 \\
\hline
\end{tabular}

\section{Discussion of Results}

The results of the study showed that Zinc had the highest concentration in the Lungfish samples investigated followed by Lead while Cadmium was below the detection limit (not detected). The high concentrations of Zinc and Lead encountered in this study can be attributed to corrosion and leaching of old piping in the water and sewage distribution system, old paint pigments, lead pencils, anti-pest products in insecticides, fungicides, rat poisons, wood preservatives, deodorants, cosmetics, medicines, ointments and printing ink $[1,2]$. A significant difference $(p<0.05)$ was observed in the bioconcentration of Lead and Zinc. This observation is concordant with the conclusions of Watanabe et al [39] and Masoud et al [40] that absorbency of heavy metals in animal tissues varies from one trace metal to another. It is worth noting that the mean trace metal concentrations in the lungfishes followed the sequence $\mathrm{Zinc}>\mathrm{Lead}>\mathrm{Cadmium}$. This trend is a typical second order polynomial as shown in Figure 3.

\subsection{Zinc}

There was no statistically significant difference in the concentration of Zinc in the lungfish samples from the different sluices of the lagoon. The statistical mean concentrations of Zinc in the lung fishes from down, middle and up streams in $\mathrm{mg} / \mathrm{kg}$ were $157.8 \pm 0.01,160.2 \pm 0.02$ and $158.2 \pm 0.01$ respectively. This result is comparable with the findings of Morrison et al [41] and Kudakwashe and Jabulani [42] who found that Zinc concentrations in some selected South African sewage sludges were in elevated ranges of 951.25 to $1,732 \mathrm{mg} / \mathrm{kg}$. The high concentration of Zinc could be because the sewage being disposed in the lagoon have a large amount of Zinc compounds in form of zinc-based paints, zinc alloys, dry cells, old and rusty galvanized roofing iron sheets and varnishes. Zinc is a constituent of galvanized steel including water distribution pipes and a close possibility is that its presence might be due to corrosion that ferried the trace metal into the lagoon [43]. The highest concentration of Zinc observed in the fish from the middle stream could be due to accumulation of the sludge in the middle stream before they can be further carried away to the downstream. More so, the period in which this investigation was done was a dry season in which no rain was experienced for a spell of about one month thus the wastes were not carried away from the middle stream. Zinc is an essential heavy metal [44] but the concentration reported in this study is detrimental to aquatic and human health.

\subsection{Lead}

Lead was at statistical mean concentrations of $6.84 \pm 0.01$, $1.69 \pm 0.03$ and $5.12 \pm 0.01 \mathrm{mg} / \mathrm{kg}$ in the lungfishes from down, mid and up streams respectively. The observed concentration of Lead could probably be because of the use of leaded petrol and thoughtless dumping of dead car lead acid accumulators. This is supported by the fact that there are over 15 petrol stations within the municipality dealing in leaded petrol [1]. Lead is a toxic non-biodegradable and non-essential trace metal even at meagre concentrations. Thus, even at the concentration reported in this study, it is harmful to fish [45] and humans when ingested or inhaled in high doses [46]. Lead is an antagonist that interferes with fundamental trace metals of comparable characteristics such as Calcium and Zinc. It is also associated with human kidney failure and liver degradation [46]. Lead retards interactive, survival, growth, development and metabolic processes, in addition to increasing mucus synthesis [47] and triggering nervous system disorders.

\subsection{Cadmium}

No cadmium was detected in the edible muscles of the fish in this study. This could be because it is available in concentrations that are below the detection limit. Furthermore, the low levels of Cadmium could be because of its low level of accumulation in the muscle but could be present in other organs of high accumulation such as liver and kidney and it may probably be due to the use of rubber tyres [41]. This is corroborated by the fact that Cuk-Atat market is characterized by making of local foot wares called "olal" from old (used) rubber tyres (Figure 1:(a)). Cadmium can be bioconcentrated with metallothioneins with up to $330 \mathrm{mg}$ per day intake regarded toxic and up to $9 \mathrm{mg}$ per day lethal for humans. Cadmium injures kidneys and causes high blood pressure, cancerous growths, reduced reproductive capacity and hepatic dysfunction in humans. Cadmium is also implicated in calcium uptake inhibition and impairment of subsequent retention in bones.

\subsection{Toxicity Indices of the Lung Fish Samples}

The statistical EDI was in the range of 26.27 to 26.66 $\mathrm{mg} / \mathrm{kg} / \mathrm{day}$ for Zinc and 0.28 to $1.48 \mathrm{mg} / \mathrm{kg} /$ day for Lead. Health Risk Indices (HRIs) due to Zinc, Lead and Chromium in the down, middle and up slices chosen are presented in Table 2. All the HRI were greater than unity except for Chromium that was completely undetected. A heightened average HRI of 88.67 for Zinc was observed in the middle 
stream lungfish samples while Lead had the lowest HRI of 2.00 in the middle stream of the lagoon. Thus, consumption of the extant East African gilled lungfish from LML poses serious health hazards due to toxic Zinc and Lead found in the lungfish.

\section{Conclusion and Recommendations}

Lungfish from Lira Municipal lagoon contains excessive amounts of Zinc and Lead. The amounts of these heavy metals present a health risk to the consumers of the Lungfish. The levels of Zinc and Lead in the lungfish are much above the permissible limits though Cadmium was not detected. Priority trace metals (Zinc and Lead) pollution is currently a threat to Lira Municipal lagoon and may worsen with increasing anthropogenic activities. The strategy lies in Municipal authority putting a restriction against catching lungfish from the lagoon. The lagoon area should be isolated and fenced to avoid unauthorized access. Cadmium detection should be carried out on other parts of high bioaccumulation such as liver and kidney and with more sensitive methods. Other active metabolic tissues of the lung fish such as the liver and intestines should be analyzed for heavy metals.

\section{Acknowledgements}

Thanks to the Environment officer and Engineer of National Water and Sewage Corporation-Lira for their official permission that made obtaining the lungfish samples possible. We are grateful to the Government of the Republic of Uganda through the Higher Education Scheme Financial Board (HESFB) for the loan offered to Remish Ogwang to finance his University education that thus led to the realization of this research. Lastly to Mr. Ssebulime Stephen, Richard and the Management of Directorate of Government Analytical Laboratories (DGAL), Plot 2, Lourdel Road, Nakasero Wandegeya-Kampala for their technical services towards the spectroscopic analysis of the Lung fish samples.

\section{References}

[1] Lira Municipal Council. "Environmental Impact Statement for the Proposed Waste Composting Plant and Landfill in Aler Village, Anyomorem Parish, Adekokwok Subcounty, Lira District". pp. 1-83, 2008.

[2] Uganda National Bureau of Statistics (UBOS). "Lira Municipal Statistical abstract". pp. 1-51, 2012.

[3] A. Türkmen, M. Türkmen, Y. Tepe and I. Akyurt. "Heavy metals in three commercially valuable fish species from İskenderun Bay, Northern East Mediterranean Sea, Turkey". Food Chemistry, vol. 91, no. 1, pp. 167-172, 2005.

[4] M. Canli and G. Atli. "The relationships between heavy metal $(\mathrm{Cd}, \mathrm{Cr}, \mathrm{Cu}, \mathrm{Fe}, \mathrm{Pb}, \mathrm{Zn})$ levels and the size of six Mediterranean fish species". Environmental Pollution, vol. 121, pp. 129-136, 2003.
[5] M. Dural, L. Z. M. Göksu, A. A. Özak and B. Derici. "Bioaccumulation of some heavy metals in different tissues of Dicentrachus labrax L, 1758, Sparus aurata L, 1758 and Mugil cephalus L, 1758 from the Camlik Lagoon of the Eastern coast of Mediterranean (Turkey)". Environmental Monitoring Assessment, vol. 18, pp. 65-74, 2006.

[6] A. R. Goyer. "Toxic metals and essential metal interactions". Annual Review of Nutrition, vol. 17, pp. 37-50, 1997.

[7] I. Papagiannis, I. Kagalou, J. Leonardos, D. Petridis and V. I. K Kalfakakou, V. Kalfakakou. "Copper and Zinc in four freshwater fish species from Lake Pamvotis (Greece)". Environment International, vol. 30, no. 3, pp. 357-362, 2004.

[8] C. Fernandes, A. Fontaínhas-Fernandes, F. Peixoto and M. A. Salgado. "Bioaccumulation of heavy metals in Liza saliens from the Esmoriz-Paramos coastal lagoon, Portugal". Ecotoxicology and Environmental Safety, vol. 66, no. 3, pp. 426-31, 2007.

[9] H. Y. Lai, Z. Y. Hseu., T. C. Chen, B. C. Chen, H. Y. Guo \& Z. S. Chen. "Health risk-based assessment and management of heavy metals-contaminated soil sites in Taiwan". International Journal of Environmental Research and Public Health, vol. 7, pp. 3595-3614, 2010.

[10] G. F. John \& B. A. Andrew. "Lead isotopic study of the human bioaccessibility of Lead in urban soils from Glasgow, Scotland". Science of the Total Environment, vol. 409, pp. 4958-65, 2011.

[11] I. Hiroaki, I. Motoki, S. Norie, T. Ribeka, K. Yoshio and Y. Shiro. "Dietary cadmium intake and breast cancer risk in Japanese women: A case-control study". International Journal of Hygiene and Environmental Health, vol. 217, pp. 70-77, 2013.

[12] Z. Birungi, B. Masola, M. F. Zaranyika, I. Naigaga and B. Marshall. "Active biomonitoring of trace heavy metals using fish (Oreochromis niloticus) as bioindicator species. The case of Nakivubo wetland along Lake Victoria". Physics and Chemistry of the Earth Parts $A / B / C$ 32(15-18), pp. 1350-58, 2007.

[13] FAO. "Compilation of legal limits for hazardous substances in fish and fishery products". FAO Fish Circ, vol. 5, pp. 464, 1983.

[14] European Comission. "Commission Regulation (EC) No 466/2001 of 8 March 2001". Official Journal of European Communities, 1.77/1, 2011.

[15] FDA. "Fish and Fisheries Products Hazards and Controls Guidance". USA: Center for Food Safety and Applied Nutrition, US Food and Drug Administration, 2001.

[16] R. N. Gibson. "Impact of habitat quality and quantity on the recruitment of juvenile flatfishes". Netherlands Journal of Sea Research, vol. 32, pp. 191, 1994.

[17] S. Said, A. Aribarg, P. Virutamsen, S. Chutivongse, S. Koetsawang, P. Meherjee, T. Kumar, A. Cuadros. "The influence of varicocele on parameters of fertility in a large group of men presenting to infertility clinics". Fertility and Sterility, vol. 57, pp. 1289-93, 1992.

[18] J. Burger, K. F. Gaines, C. S. Boring, W. L. Stephens, J. Snodgrass, and C. Dixon. "Metal levels in fish from the Savannah River: potential hazards to fish and other receptors". Environmental Research, Section A, vol. 89, pp. 85-97, 2002. 
[19] A. K. Ahmed and M. Shuhaimi-Othman. "Heavy metal concentrations in sediments and fishes from Lake Chini, Pahang, Malaysia". Journal of Biological Sciences, vol. 10, no. 2, pp. 93-100, 2010.

[20] Al-Kahtani, N. "Accumulation of Heavy Metals in Tilapia Fish (Oreochromis niloticus)". American Journal of Applied Sciences, vol. 6, no. 12, pp. 2024-29, 2009.

[21] Y. B. M. Koca, S. Koca, S. Yildiz, B. Gurcu, E. Osanc and O. Tuncbas. "Investigation of histopathological and cytogenetic effects on Lepomis gibbosus (Pisces: Perciformes) in the Cine stream (Aydin/Turkey) with determination of water pollution". Environmental Toxicology, vol. 20, pp. 560-71, 2005.

[22] B. Jezierska and M. Witeska. "The metal uptake and accumulation in fish living in polluted waters". Journal of Springer, vol. 12, pp. 108-10, 2006.

[23] P. Weber, E. R. Behr, C. D. L. Knorr, D. S. Vendruscolo, E. M. M. Flores, V. L. Dressler \& B. Baldisserotto, "Metals in the water, sediment, and tissues of two fish species from different trophic levels in a subtropical Brazilian river". Microchemical Journal, vol. 106, pp. 61-66, 2013.

[24] S. Adhikari \& Ghosh, Lopa \& S Giri, B \& Ayyappan, Silambarasan. "Distributions of metals in the food web of fishponds of Kolleru Lake, India". Ecotoxicology and environmental safety, vol. 72, pp. 1242-48, 2008.

[25] R. Hashim, T. H. Song, N. Z. Md Muslim, T. P. Yen. "Determination of Heavy Metal Levels in Fishes from the Lower Reach of the Kelantan River, Kelantan, Malaysia". Tropical Life Sciences Research, vol. 25, no. 2, pp. 21-39, 2014.

[26] M. E. Mostafa, S. F. Rabie, A. D. Aida, F. Mohammad. "Assessment of Heavy Metals Concentration in Water and Edible Tissues of Nile Tilapia (Oreochromis niloticus) from two Fish Farms Irrigated with Different Water Sources, Egypt". International Journal of Environment, vol. 4, no.1, pp. 108-115, 2015.

[27] M. Anand and P. Kumarasamy. "Analysis of heavy metals in fish samples along the east coastal region of Valinokkam, Ramanathapuram District, Tamilnadu". Advances in Applied Science Research, vol. 4, no. 6, pp. 178-183, 2013.

[28] G. Darko, D. Azanu and N. K. Logo. "Accumulation of toxic metals in fish raised from sewage-fed aquaculture and estimated health risks associated with their consumption". Cogent Environmental Science, vol. 2, pp. 1190116, 2016.

[29] M. N. H. Shovon, B. Majumdar, Z. Rahman. "Heavy Metals (Lead, Cadmium and Nickel) Concentration in Different rgans of Three Commonly Consumed Fishes in Bangladesh". Fisheries and Aquaculture Journal, vol. 8, no. 3, pp. 1000207, 2017.

[30] G. W. A Nyakairu, C. B. Nagawa, J. Mbabazi. "Assessment of cyanobacteria toxins in freshwater fish: A case study of Murchison Bay (Lake Victoria) and Lake Mburo, Uganda". Toxicon, vol. 55, no. 5, pp. 939-46, 2009.

[31] P. Ogwok, J. H. Muyonga, M. L. Sserunjogi. "Pesticide Residues and Heavy Metals in Lake Victoria Nile Perch, Lates niloticus, Belly Flap Oil". Bulleting of Environmental Contamamination and Toxicology, vol. 82, no. 5, pp. 529-533, 2009.

[32] C. Munabi, F. Kansiime, A. Amel. "Variation of water quality in Kakira catchment area, Jinja- Uganda". Physics and Chemistry of the Earth Parts A/B/C, vol. 34, pp. 761-766, 2009.

[33] US EPA. "Risk-based concentration table". United States Environmental Protection Agency: Washington, DC, 2009.

[34] X. Wang, T. Sato, B. Xing, \& S. Tao. "Health risks of heavy metals to the general public in Tianjin, China via consumption of vegetables and fish". Science of The Total Environment, vol. 350, pp. 28-37, 2005.

[35] M. Bamuwamye, P. Ogwok, V. Tumuhairwe, R. Eragu, H. Nakisozi and P. E. Ogwang. "Dietary content and potential health risks of metals in commercial black tea in Kampala (Uganda)". Journal of Food Research, vol.6, no.6, pp. 1-12, 2017.

[36] M. Ali and V. T. B. Hau."Vegetables. In Bangladesh: Economic and nutritional impact of new varieties and technologies. Technical bulleting No.25 Tainan, Taiwan". The World Vegetable Center (AVRDC), 2001.

[37] N. Saha \& M. R. Zaman. "Evaluation of possible health risks of heavy metals by consumption of foodstuffs available in the central market of Rajshahi City, Bangladesh". Environmental monitoring and assessment, vol. 185, pp. 3867-78, 2012.

[38] N. Bortey-Sam, S. M. M. Nakayama, Y. Ikenaka, O. Akoto, E. Baidoo, Y. B. Yohannes and M. Ishizuka. "Human health risks from metals and metalloid via consumption of food animals near gold mines in Tarkwa, Ghana: Estimation of the daily intakes and target hazard quotients (THQs)". Ecotoxicology and Environmental Safety, vol. 111, pp. 160-67, 2005.

[39] K. H. Watanabe, F. W. Desimone, A. Thiyagarajah, W. R. Hartley and A. E. Hindrichs. "Fish tissue quality in the lower Mississippi River and health risks from fish consumption". Science of Total Environment, vol. 302, pp. 109-26, 2003.

[40] M. S. Masoud, M. I. El-Samra and M. M. El-Sadawy. "Heavy-metal distribution and risk assessment of sediment and fish from El-Mex Bay, Alexandria, Egypt". Chemical Ecology, vol. 23, pp. 201-16, 2007.

[41] G. Morrison, O. Fatoki, S. Linder and C. Lundehn. "Determination of heavy metal concentrations and metal fingerprints of sewage sludge from Eastern Cape Province South Africa by ICP-MS and LA-ICP-MS". Water, Air and Soil Pollution, vol. 152, pp. 111-27, 2004.

[42] K. S. Kudakwashe and R. G. Jabulani. "Assessment of Heavy Metals in Municipal Sewage Sludge: A Case Study of Limpopo Province, South Africa". International Journal of Environmental Research and Public Health, vol. 11, pp. 2569-79, 2014.

[43] B. Pawlowski, K. Krawczyk and P. Bala. "The premature deterioration of Zinc-coated steel pipes in water distribution system". International Journal of Materials and Mechanical Engingeering, vol. 2, pp. 43-47, 2013.

[44] C. Hogstrand and C. Haux. "Binding and detoxification of heavy metals in lower vertebrates with reference to metallothionein". Comparative Biochemistry and Physiology Part C, vol. 100, pp. 137, 2000.

[45] A. M. Badr, N. A. Mahana, and A. Eissa. "Assessment of Heavy Metal Levels in Water and Their Toxicity in Some Tissues of Nile Tilapia (Oreochromis niloticus) in River Nile Basin at Greater Cairo, Egypt". Global Veterinaria, vol. 13, no. 4, pp. 432-43, 2014. 
[46] H. M. Salem, E. A. Eweida and A. Farag. "Heavy metals in drinking water and their environmental impact on human health". in The International Conference for Environmental Hazard Mitigation ICEHM 2000. 9-12 September 2000, Cairo University, Cairo, Egypt.
[47] R. Eisler. "Lead hazards to fish, wildlife and invertebrates: A synoptic review", pp. 1-14, 1988. 